\title{
Inclusion of alternative marine by-products in aquafeeds with different levels of plant-based sources for on-growing gilthead sea bream (Sparus aurata, L.): effects on digestibility, amino acid retention, ammonia excretion and enzyme activity
}

Guillem Estruch, Ana Tomás-Vidal, Asmaa M. El Nokrashy, Raquel MongeOrtiz, Sergio Godoy-Olmos, Miguel Jover Cerdá \& Silvia Martínez-Llorens

To cite this article: Guillem Estruch, Ana Tomás-Vidal, Asmaa M. El Nokrashy, Raquel Monge-Ortiz, Sergio Godoy-Olmos, Miguel Jover Cerdá \& Silvia Martínez-Llorens (2018): Inclusion of alternative marine by-products in aquafeeds with different levels of plant-based sources for on-growing gilthead sea bream (Sparus aurata, L.): effects on digestibility, amino acid retention, ammonia excretion and enzyme activity, Archives of Animal Nutrition, DOI: 10.1080/1745039X.2018.1472408

To link to this article: https://doi.org/10.1080/1745039X.2018.1472408

Published online: 07 Jun 2018.

山 Article views: 1
Submit your article to this journal $\llbracket$

View related articles $\longleftarrow$

View Crossmark data $\sqsubset$ 


\section{Inclusion of alternative marine by-products in aquafeeds with different levels of plant-based sources for on-growing gilthead sea bream (Sparus aurata, L.): effects on digestibility, amino acid retention, ammonia excretion and enzyme activity}

Guillem Estruch $\mathbb{B}^{\mathrm{a}}{ }^{\mathrm{a}}$, Ana Tomás-Vidal ${ }^{\mathrm{a}}$, Asmaa M. El Nokrashy ${ }^{\mathrm{b}}$, Raquel Monge-Ortiz ${ }^{\mathrm{a}}$, Sergio Godoy-Olmos (10), Miguel Jover Cerdáa and Silvia Martínez-Llorens (10 ${ }^{a}$

aResearch Group of Aquaculture and Biodiversity, Institute of Animal Science and Technology, Universitat Politècnica de València, València, Spain; ${ }^{b}$ Marine Hatchery and Aquaculture Department, Faculty of Aquatic and Fisheries Science, Kafrelsheikh University, Kafr Elsheikh, Egypt

\begin{abstract}
The search for new sustainable aquafeeds for the species with greater economic importance, such as the gilthead sea bream in Europe, is one of the main challenges in the aquaculture sector. The present work tested fishmeal replacement by a mixture of plant meals at different levels, as well as the use of marine byproducts with attractant properties and high-quality protein in high plant protein diets. In order to do that, effects on growth and biometric parameters, digestibility, amino acid retention, excreted ammonia and proteases and amylase activity were assessed, using six different diets: FM100 (100\% of protein provided by fishmeal), FM50 (50\% of replacement), FM25 (75\% of replacement) and FMO (100\% of replacement), but also FM25+ ( $75 \%$ of replacement and $15 \%$ of squid and krill meal inclusion), and $\mathrm{FMO}+(100 \%$ of replacement and $15 \%$ of squid and krill meal inclusion). In group FM0, a clear impact of dietary changes was observed on growth, survival and ammonia excretion. Amino acid retention in group $\mathrm{FMO}$ + was also significantly affected, which can be explained by the limited content of certain amino acids in this diet. On the other hand, no significant differences were observed in most biometric parameters or in enzyme activity. In conclusion, complete fishmeal replacement can be achieved by using a mixture of plant-based sources, but supplementation with complementary marine ingredients can prevent detrimental effects on growth, survival, nutritional parameters and protein metabolism.
\end{abstract}

\section{ARTICLE HISTORY}

Received 30 January 2018

Accepted 30 April 2018

\section{KEYWORDS}

Gilthead sea bream; vegetable protein; krill meal; ammonia nitrogen; digestibility; enzyme activity

\section{Introduction}

Fishmeal has traditionally been used as the main ingredient in diets for carnivorous fish, due to its high content in high-quality protein and its digestibility and palatability. Nevertheless, the reduced availability of this product and the increase of its price demand finding alternative protein sources. As a carnivorous species, the gilthead sea 
bream (Sparus aurata, L.) needs a high level of protein in aquafeeds. Plant-based sources, such as oilseed and cereals and their by-products, have a stable nutritional composition and high market availability. Wheat and corn gluten (Pereira and OlivaTeles 2003), lupin meal (Pereira and Oliva-Teles 2004), pea meal (Pereira and OlivaTeles 2002), rapeseed meal (Gómez-Requeni et al. 2004), soybean meal (MartínezLlorens et al. 2007), among other single ingredients, have been studied as fishmeal replacements in gilthead sea bream. However, the use of plant ingredients has some drawbacks, such as low digestibility, imbalances in essential amino acids (EAA) and low palatability.

On the one hand, the high content in non-starch polysaccharides (NSP), observed in plant meals (Francis et al. 2001), can alter the activity of the different digestive enzymes, which affects the digestion and absorption of nutrients (Fountoulaki et al. 2005) and, as a consequence, the growth performance of fish. Carnivorous fish are not able to efficiently digest carbohydrates, but use them as a source of energy when found in high proportions in diets, which leads to impaired growth parameters (Bowyer et al. 2013). Different effects of different plant-based sources on the activity of various digestive enzymes have been reported in different species (Bowyer et al. 2013; Hartviksen et al. 2014), including gilthead sea bream (Santigosa et al. 2008).

On the other hand, insufficient levels of EAA can be partially solved by using diverse plant-based sources in feeds, as a consequence of the complementation between different amino acids profiles present in the various plant sources. In fact, best results in sea bream growth assays have been achieved with partial substitutions of fishmeal with mixtures of different plant ingredients (De Francesco et al. 2007; Dias et al. 2009; Sánchez-Lozano et al. 2009). Moreover, certain studies (Kissil and Lupatsch 2004; Monge-Ortiz et al. 2016) have been able to formulate a feed with total substitution of the fishmeal by vegetable ingredients. Nevertheless, the required amino acid profile for on-growing sea bream fed only plant protein sources can just be achieved by supplementing free amino acids (Monge-Ortiz et al. 2016) or by including complementary ingredients, in order to combat the nutritional deficiencies of these diets (Kader et al. 2012).

Lastly, the use of attractants in fish feed is necessary to minimise the negative impact of plant meals in growth rate (Gomes et al. 1995; Venou et al. 2003) and improve palatability and feed intake. Different kinds of attractants, like chemical attractants or extracts of marine organisms such as krill meal (Torstensen et al. 2008), have been tested. Moreover, marine by-products also show a balanced amino acid profile closer to fishmeal and provide free amino acids (Kader et al. 2012), which improves the amino acid profile of high plant protein diets by complementing some of the deficiencies of plant-based diets (Kolkovski et al. 2000; Mai et al. 2006) and reducing the level of supplementation with crystalline amino acids.

The inclusion of squid and krill meal in diets for gilthead sea bream has been previously assessed. Nevertheless, most of the studies focus on larvae (Kolkovski et al. 2000; Cahu and Zambonino Infante 2001) or small fish (Kader et al. 2010, 2012). Moreover, research works with larger fish in which these alternative ingredients have been used in diets with high levels of plant protein also include high levels of free amino acids, leading to mixtures more expensive than fishmeal-based diets (Monge-Ortiz et al. 2016). Therefore, the main goal of the present research work was to assess the impact of different levels of inclusion of a plant protein mixture in aquafeeds on the growth and 
digestive performance of on-growing gilthead sea bream. To achieve the minimum requirements of EAA for the on-growing gilthead sea bream, diets were supplemented with crystalline amino acids and, in the case of high partial or total replacement, the inclusion of squid and krill meal as complementary ingredients was also tested in order to improve the essential amino acid profile of the experimental diets. The impact of the different diets on biometrics, biochemical composition, digestion and retention of essential and non-EAA, ammonia excretion and digestive enzyme activities was also evaluated.

\section{Materials and methods}

\subsection{Experimental setup}

The growth assay was conducted in 18 cylindrical fiberglass tanks (1750 1) within a marine water recirculating system $\left(75 \mathrm{~m}^{3}\right.$ capacity) with a rotary mechanical filter and a gravity biofilter $\left(6 \mathrm{~m}^{3}\right.$ capacity) in the Universitat Politècnica de València (UPV). All tanks were equipped with aeration and the water was heated with a heat pump installed in the system. During the experiment, water conditions were as follows: $23 \pm 1.5{ }^{\circ} \mathrm{C}, 30 \pm 1.7 \mathrm{~g} / \mathrm{L}$ salinity, $6 \pm 0.5 \mathrm{mg} \mathrm{O} / \mathrm{L}$ and $\mathrm{pH}$ 7.5. All tanks had similar lighting conditions with a natural photoperiod (from November-March, with an average of $11 \mathrm{~h}$ of light).

\subsection{Fish}

Sea bream were obtained from the fish farm PISCIMAR in Burriana (Valencia, Spain). Fish acclimated to laboratory conditions for 2 weeks, feeding a standard commercial diet with a proximal composition of $48 \%$ crude protein (CP), $23 \%$ ether extract (EE), $11 \%$ crude ash (CA), $2 \%$ crude fibre (CF) and 14\% nitrogen free extractives (NFE). Then, the 360 fish were randomly distributed in the 18 tanks, in groups of 20 in each one. The experiment was initiated with fish weighing $128 \pm 5.3 \mathrm{~g}$.

\subsection{Ethics statements}

The experimental protocol was reviewed and approved by the Committee of Ethics and Animal Welfare of the UPV, following the Spanish Royal Decree 53/2013 on protection of animals used for scientific purposes (Boletín Oficial del Estado 2013).

\subsection{Diets}

Six isonitrogenous and isoenergetic diets were formulated (FM100, FM50, FM25+, FM25, FM0+ and FM0). They differed in the level of fishmeal, the inclusion of krill and squid meal as attractants, and the addition of different synthetic crystalline amino acids. Various levels of fishmeal replacement were tested: 0\% (FM100), 50\% (FM50), 75\% (FM25+ and FM25) and 100\% (FM0+ and FM0). Diets FM25+ and FM0+ included alternative marine by-products (15\%) from different companies: squid meal (Max Nollert, Utrecht, Netherlands), at 10\% level, and squid meal (Ludan Renewable 
Energy, Valencia, Spain), at 5\%. All diets, except for FM100, were supplemented with free amino acids in order to meet the optimum amino acid requirements for gilthead sea bream (Peres and Oliva-Teles 2009). The formulation of experimental diets, essential amino acid dietary content and amino acid optimum requirements for the ongrowing gilthead sea bream are shown in Table 1.

All diets were prepared as pellets by cooking-extrusion using a semi-industrial twinscrew extruder (CLEXTRAL BC-45, Firminy, St Etienne, France) located at the UPV. The processing conditions were as follows: $100 \mathrm{rpm}$ screw speed, $110{ }^{\circ} \mathrm{C}, 40 \mathrm{~atm}$ pressure and 3-5 $\mathrm{mm}$ diameter pellets.

Table 1. Formulation and proximate composition of experimental diets.

\begin{tabular}{|c|c|c|c|c|c|c|c|}
\hline & FM100 & FM50 & FM25+ & FM25 & FM0+ & FM0 & Optimum $\pi$ \\
\hline \multicolumn{8}{|l|}{ Ingredients $[\mathrm{g} / \mathrm{kg}]$} \\
\hline Fishmeal & 589 & 295 & 150 & 150 & & & \\
\hline Wheat meal & 260 & 66 & 60 & & & & \\
\hline Wheat gluten & & 130 & 125 & 220 & 222 & 295 & \\
\hline Soybean meal & & 130 & 132 & 160 & 160 & 182 & \\
\hline Bean meal & & 25 & 25 & 42 & 40 & 41 & \\
\hline Pea meal & & 25 & 25 & 42 & 40 & 41 & \\
\hline Sunflower meal & & 130 & 132 & 160 & 160 & 158 & \\
\hline Squid meal & & & 100 & & 100 & & \\
\hline Krill meal & & & 50 & & 50 & & \\
\hline Fish oil & 38 & 64 & 78 & 77 & 90 & 90 & \\
\hline Soybean oil & 93 & 91 & 66 & 91 & 65 & 90 & \\
\hline Soy lecithin & 10 & 10 & 10 & 10 & 10 & 10 & \\
\hline Vitamin-mineral mix* & 10 & 10 & 10 & 10 & 10 & 10 & \\
\hline Monocalcium phosphate & & 19 & 27 & 28 & 38 & 38 & \\
\hline Taurine & & & & & & 20 & \\
\hline DL-Methionine & & 5 & 5 & 5 & 5 & 7 & \\
\hline L-Lysine- $\mathrm{HCl}$ & & & 5 & 5 & 10 & 10 & \\
\hline L-Arginine & & & & & & 5 & \\
\hline L-Threonine & & & & & & 3 & \\
\hline \multicolumn{8}{|l|}{ Proximate composition } \\
\hline Dry matter (DM) $[\mathrm{g} / \mathrm{kg}$ fresh matter $]$ & 881 & 914 & 902 & 928 & 928 & 939 & \\
\hline Crude protein $[\mathrm{g} / \mathrm{kg} \mathrm{DM}]$ & 442 & 447 & 445 & 450 & 446 & 451 & \\
\hline Ether extract $[\mathrm{g} / \mathrm{kg} \mathrm{DM}]$ & 185 & 193 & 201 & 210 & 200 & 198 & \\
\hline Crude ash [g/kg DM] & 101 & 98 & 101 & 90 & 88 & 75 & \\
\hline Crude fibre $[\mathrm{g} / \mathrm{kg} \mathrm{DM}]$ & 10 & 35 & 39 & 42 & 46 & 42 & \\
\hline Nitrogen free extractives ${ }^{\ddagger}[\mathrm{g} / \mathrm{kg} \mathrm{DM}]$ & 260 & 219 & 214 & 213 & 209 & 222 & \\
\hline Non-starch polysaccharides [g/kg DM] & 109 & 175 & 178 & 197 & 199 & 206 & \\
\hline \multicolumn{8}{|l|}{ Essential amino acids $[\mathrm{g} / 100 \mathrm{~g} \mathrm{DM}]$} \\
\hline Arginine & 3.39 & 3.87 & 3.86 & 3.16 & 3.58 & 3.30 & 2.50 \\
\hline Histidine & 1.00 & 1.11 & 0.81 & 0.90 & 0.81 & 0.82 & 0.85 \\
\hline Isoleucine & 1.47 & 1.30 & 1.24 & 1.26 & 1.08 & 1.17 & 1.15 \\
\hline Leucine & 3.24 & 2.84 & 3.11 & 3.03 & 2.45 & 2.98 & 2.24 \\
\hline Lysine & 3.68 & 2.60 & 2.78 & 2.12 & 2.38 & 2.26 & 2.31 \\
\hline Methionine & 1.16 & 1.14 & 1.06 & 1.09 & 1.05 & 1.06 & 1.17 \\
\hline Phenylalanine & 1.80 & 1.75 & 1.78 & 1.67 & 1.76 & 1.87 & \\
\hline Threonine & 1.98 & 1.66 & 1.50 & 1.45 & 1.28 & 1.44 & 1.34 \\
\hline Valine & 2.01 & 1.67 & 1.60 & 1.57 & 1.32 & 1.47 & 1.44 \\
\hline
\end{tabular}

*Provided per kilogramme complete diet: $5 \mathrm{~g}$ premix, $2 \mathrm{~g}$ choline, $1 \mathrm{~g}$ DL- $a$-tocopherol, $1 \mathrm{~g}$ ascorbic acid, $1 \mathrm{~g} \mathrm{Ca}_{3}\left(\mathrm{PO}_{4}\right)_{2}$; premix provided per kilogramme diet: $10000 \mathrm{IU}$ retinol acetate, $5 \mathrm{IU}$ calcipherol, $0.1 \mathrm{~g} \mathrm{DL}-\alpha$-tocopherol, $8 \mathrm{mg}$ menadione sodium bisulphite, $23 \mathrm{mg}$ thiamine $23 \mathrm{mg}$ riboflavin, $150 \mathrm{mg}$ pyridoxine hydrochloride, $0.25 \mathrm{mg}$ cyanocobalamine; $150 \mathrm{mg}$ nicotinamide, $60 \mathrm{mg}$ pantothenic acid, $6.5 \mathrm{mg}$ folic acid, $0.7 \mathrm{mg}$ biotin, $750 \mathrm{mg}$ ascorbic acid, $150 \mathrm{mg}$ inositol, $1 \mathrm{~g}$ betaine, $120 \mathrm{mg}$ polypeptides.

${ }^{\ddagger}$ Nitrogen free extractives (NFE) $=1000$ - Crude protein - Ether extract - Crude ash - Crude fibre

"Optimum essential amino acid profile according to Peres and Oliva-Teles (2009). 


\subsection{Biochemical analyses}

The diets, their ingredients, fish and faeces were analysed according to the Association of Official Agricultural Chemists (AOAC 1995) procedures: dry matter (DM) by heating at $105{ }^{\circ} \mathrm{C}$ to constant weight (2001.12), CA by incineration at $550{ }^{\circ} \mathrm{C}$ to constant weight (942.05), CP, N $\cdot 6.25$, by the Kjeldahl method after an acid digestion (Kjeltec 2300 Auto Analyser, Tecator Höganas, Sweden; 954.01), EE by methyl-ether extraction (Soxtec 1043 extraction unit, Tecator; 920.39) and CF by acid and basic digestion (Fibertec System M., 1020 Hot Extractor, Tecator; 989.03). All analyses were performed in triplicate except for faeces. Chemical analyses of ingredients were determined prior to diet formulation. Proximate composition of experimental diets is shown in Table 1.

\subsubsection{Amino acid analysis}

Amino acids of raw materials, experimental diets, fish (five per tank) and faeces were analysed prior to diet formulation through a Waters HPLC system (Waters 474, Waters, Milford, MA, USA) consisting of two pumps (Model 515, Waters), an auto sampler (Model 717, Waters), a fluorescence detector (Model 474, Waters) and a temperature control module, following the method described by Bosch et al. (2006). Aminobutyric acid was added as an internal standard pattern before hydrolysation. The amino acids were derivatised with AQC (6aminoquinolyl-N-hydroxysuccinimidyl carbamate). Methionine and cysteine were determined separately as methionine sulphone and cysteic acid after oxidation with performic acid. Amino acids were separated with a C-18 reverse-phase column Waters Acc. Tag (150 $\mathrm{mm} \times 3.9 \mathrm{~mm}$ ) and then transformed to methionine and cysteine. Essential and non-essential amino acid content of different ingredients are shown in Supplemental material (S1). The amino acid content of fish is shown in Supplemental material (S2). Retention efficiencies of ingested amino acid (AAIRE) were calculated for each experimental group.

\subsection{Growth assay}

The trial lasted $154 \mathrm{~d}$. Fish were observed daily in the tanks and were weighed individually every 4 weeks, using clove oil containing $87 \%$ eugenol (Guinama ${ }^{\circledR}$, Valencia, Spain) as an anaesthetic (1 mg/100 ml water) to minimise their suffering, in order to evaluate fish growth along the assay, determine growth parameters and asses their health status. At the end of the experiment, fish were sacrificed by cold shock after anaesthesia.

Each of the six experimental diets was randomly assigned to three tanks (triplicate groups). Fish were fed by hand twice a day (9:00 h and 17:00 h) to apparent satiation, distributing the pellets slowly, allowing all fish to eat and making sure no feed remained at the bottom of the tanks, in a weekly regime of $6 \mathrm{~d}$ of feeding and one of fasting.

The growth and nutrient efficiency and utilisation indices considered were: feed intake (FI), feed conversion ratio (FCR), protein efficiency ratio (PER) and protein productive value (PPV). Survival rate (S) was also determined.

$$
\begin{gathered}
\mathrm{FI}=100 \cdot \frac{\text { Feed consumption }[\mathrm{g}]}{\text { Average biomass }[\mathrm{g}] \cdot \text { Time }[\mathrm{d}]} \\
\text { FCR }=100 \cdot \frac{\text { Feed offered }[\mathrm{g}]}{\text { Weight gain }[\mathrm{g}]}
\end{gathered}
$$




$$
\begin{aligned}
& \text { PER }=100 \cdot \frac{\text { Weight gain }[\mathrm{g}]}{\text { Protein intake }[\mathrm{g}]} \\
& \mathrm{PPV}=100 \cdot \frac{\text { Protein gain }[\mathrm{g}]}{\text { Protein intake }[\mathrm{g}]} \\
& \mathrm{S}=100 \cdot \frac{\text { Final number of fish }}{\text { Initial number of fish }}
\end{aligned}
$$

\subsection{Biometric indices}

Condition factor $(\mathrm{K})$, viscerosomatic index (VSI), hepatosomatic index (HSI) and visceral fat index (VFI) were calculated at the end of the growth assay, using five fish per tank randomly selected.

$$
\begin{gathered}
\mathrm{K}=100 \cdot \frac{\text { Total weight }[\mathrm{g}]}{\text { Total length }\left[\mathrm{cm}^{3}\right]} \\
\mathrm{VSI}=100 \cdot \frac{\text { Visceral weight }[\mathrm{g}]}{\text { Empty fish weight }[\mathrm{g}]} \\
\mathrm{HSI}=100 \cdot \frac{\text { Liver weight }[\mathrm{g}]}{\text { Fish weight }[\mathrm{g}]} \\
\mathrm{VFI}=100 \cdot \frac{\text { Visceral fat weight }[\mathrm{g}]}{\text { Empty fish weight }[\mathrm{g}]}
\end{gathered}
$$

\subsection{Digestibility assay}

A digestibility experiment was performed after the feeding trial in six digestibility tanks of $250 \mathrm{~L}$, following the Guelph System protocol (Cho et al. 1982), using five fish per experimental group randomly selected. Before feeding, fish were fasted for $2 \mathrm{~d}$. During a period between 7 and $14 \mathrm{~d}$, until enough wet faeces for the analysis were collected, fish were fed to satiation once a day in the morning (9:00) with the same six experimental diets, but chromium oxide $\left(50 \mathrm{~g} \cdot \mathrm{kg}^{-1}\right)$ was added as an inert marker. Uneaten feed was removed from the columns (15:00). Samples of wet faeces from each tank were collected from decantation columns, just before the morning feeding, and dried at $60{ }^{\circ} \mathrm{C}$ for $48 \mathrm{~h}$ prior to analysis.

Chromium oxide was determined in the diets and faeces using an atomic absorption spectrometer (Perkin Elmer 3300, Perkin Elmer, Boston, MA, USA) after acid digestion. Analysis was performed in duplicate. CP and amino acids content in diets and faeces were used to determine apparent digestibility coefficients (ADC, Equation 1).

$$
\operatorname{ADC}_{\mathrm{N}}[\%]=100 \cdot\left[1-\left(\frac{\text { Marker in diet }[\%]}{\text { Marker in faeces [\%] }}\right)\left(\frac{\mathrm{N} \text { in faeces }[\%]}{\mathrm{N} \text { in diet }[\%]}\right)\right]
$$

where $\mathrm{N}$ is the nutrient (CPor respective amino acid)

Retention efficiencies of the digested crude protein (PDRE [\%]) and of the digested EAA (AADRE [\%]) were also calculated. 


\subsection{Ammonia excretion}

The ammonia excretion was established for the different experimental groups. Analyses were carried out following the method detailed by McGoogan and Gatlin (1999). The pump was turned off during the entire ammonia sampling period, altering the recirculating nature of the system in order to estimate the ammonia increase due to excretion, but aeration was continually provided to each tank.

Water samples were taken before feeding and then at intervals of two $\mathrm{h}$ after feeding for a 24 -h period $(0,2,4,6,8,10,12,14,16,18,20,22$ and $24 \mathrm{~h})$. Total ammonia nitrogen (TAN) concentration was measured in all water samples using the Orion ${ }^{\circledR} 4$ Star Plus probe (ThermoScientific ${ }^{\oplus}$, Waltham, Massachussets, USA) with an ammonia specific electrode. Measurements were performed following the procedures detailed by García García et al. (2011), using hydrochloric acid (J.T. Baker ${ }^{\circledast}$, Avantor ${ }^{\mathrm{TM}}$, Central Valley, USA) and sodium hydroxide (Scharlau, Scharlab, Barcelona, Spain).

Each diet was tested three different days in three different tanks $(n=9)$. Average ammonia concentrations were adjusted to fish weight and feed ingestion in the different tanks, expressing accumulated ammonia excretion and ammonia excretion per $\mathrm{h}$ in $\mathrm{mg} \cdot \mathrm{kg}$ fish $^{-1} \cdot \mathrm{kg} \mathrm{feed}^{-1}$.

\subsection{Enzymatic activity}

Digestive tracts of two fish per tank randomly selected were sampled at the end of the assay. Fish were dissected in order to obtain the digestive tract. Stomach (S) and gut (G) were stored separately at $-20{ }^{\circ} \mathrm{C}$ until enzymatic extraction.

Enzyme extracts for protease analysis were obtained by manual disaggregation, dilution in distilled water ( $1 \mathrm{~g}$ of sample: $3 \mathrm{ml}$ of distilled water) followed by homogenisation by T25 - Digital ULTRATURRAX ${ }^{\oplus}$, maintaining tubes on ice, and centrifugation at $12000 \mathrm{rpm}$ and $4{ }^{\circ} \mathrm{C}$ for $15 \mathrm{~min}$. Gut contents (GC) were removed from the tissue and diluted in distilled water (1:3) before centrifugation at $16000 \mathrm{~g}$ and $4{ }^{\circ} \mathrm{C}$ for 15 min. Supernatants were stored at $20{ }^{\circ} \mathrm{C}$ until enzyme analysis.

Pepsin assays were performed on $\mathrm{S}$ samples and total alkaline protease assays on $\mathrm{G}$ samples, while trypsin, chymotrypsin and $\alpha$-amylase assays were performed on $\mathrm{G}$ and GC samples. Total protein concentration was assayed according the Bradford procedure (Bradford 1976), using bovine serum albumin $(2 \mathrm{mg} / \mathrm{ml})$ as a standard. Enzyme activities were expressed in $\mathrm{U} / \mathrm{mg}$ of total protein for the $\mathrm{S}$ and $\mathrm{G}$ samples (Equation 2) and in $\mathrm{U} / \mathrm{mg}$ of content for the GC samples (Equation 3).

Enzyme activity of total protein (samples $\mathrm{S}$ and $\mathrm{G}$ ) $[\mathrm{U} / \mathrm{mg}]$ $=\left(\Delta\right.$ Abs $\left.\cdot\left(\mathrm{V}_{\text {total }} / \mathrm{V}_{\text {sample }}\right)\right) /($ Total protein $[\mathrm{mg} / \mathrm{ml}])$

Enzyme activity in gut content (samples GC $[\mathrm{U} / \mathrm{mg}]$

$$
=\left(\Delta \mathrm{Abs} \cdot\left(\mathrm{V}_{\text {total }} / \mathrm{V}_{\text {sample }}\right)\right) /(\text { Gut content }[\mathrm{mg} / \mathrm{ml}])
$$

where $\Delta \mathrm{Abs}$ is the increase of absorbance of the reaction per min, $\mathrm{V}_{\text {total }}$ is the total volume of the reaction (sample, buffer and substrate) and $V_{\text {sample }}$ is the volume of the sample. 


\subsubsection{Pepsin activity}

Total acid protease activity was evaluated using $0.5 \%$ haemoglobin $\mathrm{p} / \mathrm{v}$ as substrate in $100 \mathrm{mM}$ glycine - $\mathrm{HCl}$ buffer, $\mathrm{pH} 2.5$, at $280 \mathrm{~nm}$, following the method detailed by Anson (1938) and modified by Díaz-López et al. (1998). One unit of activity was defined as $1 \mu \mathrm{g}$ of tyrosine released per min (Extinction coefficient $=0.0071$ $\left.\mathrm{ml} \cdot \mu \mathrm{g}^{-1} \cdot \mathrm{cm}^{-1}\right)$.

\subsubsection{Total alkaline protease activity}

Total alkaline protease activity was tested using $1 \%$ casein $\mathrm{p} / \mathrm{v}$ as substrate in 100 $\mathrm{mM}$ Tris- $\mathrm{HCl}$ buffer containing $10 \mathrm{mM} \mathrm{CaCl}_{2}, \mathrm{pH} 7.5$, at $280 \mathrm{~nm}$, following the method detailed by Kunitz (1947) and modified by Walter (1984). One unit of activity was defined as $1 \mu \mathrm{g}$ of tyrosine released per min (Extinction coefficient $\left.=0.0071 \mathrm{ml} \cdot \mu \mathrm{g}^{-1} \cdot \mathrm{cm}^{-1}\right)$.

\subsubsection{Trypsin activity}

Trypsin activity was obtained by a kinetic assay using $\mathrm{N} \alpha$-Benzoyl-D,L-arginine p-nitroanilide $0.5 \mathrm{mM}$ as a substrate in $50 \mathrm{mM}$ Tris- $\mathrm{HCl}$ buffer containing $20 \mathrm{mM}$ $\mathrm{CaCl}_{2}, \mathrm{pH}$ 8.2, following the method developed by Erlanger et al. (1961). The increase in absorbance at $405 \mathrm{~nm}$ was measured every $30 \mathrm{~s}$ for $5 \mathrm{~min}$. One unit of activity was defined as $1 \mu \mathrm{g}$ of p-nitroanilide released per $\min$ (Extinction coefficient $=0.0637 \mathrm{ml}$. $\left.\mu \mathrm{g}^{-1} \cdot \mathrm{cm}^{-1}\right)$.

\subsubsection{Chymotrypsin activity}

Chymotrypsin activity was obtained by a kinetic assay using N-Succinyl-Ala-Ala-Pro-Phep-nitroanilide $0.5 \mathrm{mM}$ as a substrate in $200 \mathrm{mM}$ Tris- $\mathrm{HCl}$ buffer containing $50 \mathrm{mM} \mathrm{CaCl}_{2}$, pH 7.6, following the method developed by Erlanger et al. (1961). The increase in absorbance at $405 \mathrm{~nm}$ was measured every $30 \mathrm{~s}$ for $5 \mathrm{~min}$. One unit of activity was defined as $1 \mu \mathrm{g}$ of p-nitroanilide released per min (Extinction coefficient $=0.0637 \mathrm{ml} \cdot \mu \mathrm{g}^{-1} \cdot \mathrm{cm}^{-1}$ ).

\subsection{5. a-Amylase activity}

$\alpha$-Amylase activity was determined by a kinetic assay using a commercial kit (Amylase MR, Cromatest, Linear Chemicals S.L., Barcelona, Spain), following manufacturer's instructions. The increase in absorbance at $405 \mathrm{~nm}$ was measured every $30 \mathrm{~s}$ for $5 \mathrm{~min}$, after an incubation period of $1 \mathrm{~min}$. One unit of activity was defined as $1 \mu \mathrm{g}$ of 2-chloro-p-nitrophenol released per min during the enzymatic reaction at $37{ }^{\circ} \mathrm{C}$ (Extinction coefficient $=0.0818 \mathrm{ml} \cdot \mu \mathrm{g}^{-1} \cdot \mathrm{cm}^{-1}$ ).

\subsection{Statistical analysis}

Different growth and nutrient indices, biochemical parameters, biometric indices, ADC, AAIRE, AADRE, ammonia excretion indices and specific enzyme activities were analysed through an analysis of variance using the statistical package Statgraphics ${ }^{\circledR}$ Plus 5.1 (Statistical Graphics Corp., Rockville, MO, USA), with a Newman-Keuls test for the comparison of the means. Initial weight was used as a covariate in the analysis of growth indices. The results are shown as the mean \pm standard error of the mean (SEM). The level of significance was set at $p<0.05$. 


\section{Results}

\subsection{Fish growth and nutritive efficiency}

Growth and nutritive efficiency indices of the growth experiment are shown in Table 2. Statistical differences were determined in the final weight (FW), FCR, PER and PPV between groups FM25 and FM0. There were also significant differences between group FM25+ and groups FM50, FM25 and FM0 in FI. Besides, survival rate was significantly lower in group FM0.

\subsection{Biometric and body composition}

Regarding biometric parameters (Table 2), significant differences were only observed in the HSI, which was higher for group FM100 compared to FM0. No differences were detected in the proximate composition of the fish, as shown in the Supplemental material (S2).

\subsection{Digestibility and protein and amino acid retention efficiency}

No differences were observed in the amino acid composition of whole body fish between experimental groups (Supplemental material, S2).

The $A D C_{C P}, A D C_{a a}$ and $A D C_{C L}$ are shown in Table 3. Lower values were observed for all EAA in groups FM25 and FM0, while higher values were perceived for groups FM100 and FM25+. The biggest differences were detected for arginine, threonine and valine, but no statistical analysis was performed. Differences in the digestibility of $\mathrm{CP}$ and $\mathrm{EE}$ were minor (ranging from 96.5 to 92.9 for $\mathrm{CP}$ and from 98.9 to 97.3 for $\mathrm{EE}$ ), although a slight negative effect of fishmeal replacement and a slight positive effect of complementary marine ingredients could be noticed.

The PDRE and AADRE are shown in Table 4. Higher AADRE were generally obtained in group FM0+, while lower AADRE were observed in group FM100 for

Table 2. Growth, nutritive and biometric indices of gilthead sea bream fed the different experimental diets.

\begin{tabular}{|c|c|c|c|c|c|c|c|}
\hline & FM100 & FM50 & FM25+ & FM25 & FM0+ & FM0 & SEM \\
\hline $\mathrm{IW}^{\dagger}[\mathrm{g}]$ & 131.2 & 125.9 & 130.2 & 126.1 & 129.6 & 127.2 & 2.16 \\
\hline $\mathrm{FW}^{\ddagger}[\mathrm{g}]$ & $393.1^{\mathrm{ab}}$ & $401.9^{\mathrm{ab}}$ & $422.7^{\mathrm{a}}$ & $390.2^{\mathrm{ab}}$ & $384.6^{\mathrm{ab}}$ & $360.4^{b}$ & 12.53 \\
\hline 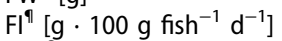 & $1.3^{\mathrm{ab}}$ & $1.4^{\mathrm{a}}$ & $1.3^{\mathrm{b}}$ & $1.4^{\mathrm{a}}$ & $1.3^{\mathrm{ab}}$ & $1.4^{\mathrm{a}}$ & 0.03 \\
\hline $\mathrm{FCR}^{5}$ & $2.1^{\mathrm{ab}}$ & $2.1^{\mathrm{ab}}$ & $1.9^{\mathrm{b}}$ & $2.3^{\mathrm{ab}}$ & $2.18^{\mathrm{ab}}$ & $2.4^{\mathrm{a}}$ & 0.09 \\
\hline $\mathrm{PER}^{\ddagger}$ & $1.1^{\mathrm{ab}}$ & $1.1^{\mathrm{ab}}$ & $1.2^{\mathrm{a}}$ & $1.0^{\mathrm{ab}}$ & $1.1^{\mathrm{ab}}$ & $0.9^{b}$ & 0.05 \\
\hline $\mathrm{PPV}^{\#}[\%]$ & $18.8^{\mathrm{ab}}$ & $18.5^{\mathrm{ab}}$ & $21.2^{\mathrm{a}}$ & $17.4^{\mathrm{ab}}$ & $20.1^{\mathrm{ab}}$ & $16.7^{\mathrm{b}}$ & 0.90 \\
\hline $\mathrm{S}[\%]$ & $88.3^{\mathrm{a}}$ & $85.0^{\mathrm{a}}$ & $88.3^{\mathrm{a}}$ & $78.3^{\mathrm{a}}$ & $86.7^{\mathrm{a}}$ & $60.0^{\mathrm{b}}$ & 5.44 \\
\hline $\mathrm{K}^{4}\left[\mathrm{~g} / \mathrm{cm}^{3}\right]$ & 1.9 & 1.9 & 1.9 & 1.7 & 1.8 & 1.7 & 0.08 \\
\hline $\mathrm{VSI}^{\circ}[\%]$ & 9.2 & 9.95 & 10.3 & 8.9 & 9.6 & 8.6 & 0.80 \\
\hline $\mathrm{HSI}^{\$}[\%]$ & $1.6^{\mathrm{a}}$ & $1.4^{\mathrm{ab}}$ & $1.3^{\mathrm{ab}}$ & $1.3^{\mathrm{ab}}$ & $1.3^{\mathrm{ab}}$ & $1.2^{\mathrm{b}}$ & 0.06 \\
\hline $\mathrm{VFI}^{\wedge}[\%]$ & 1.5 & 1.3 & 1.2 & 1.3 & 1.8 & 1.4 & 0.18 \\
\hline
\end{tabular}

${ }^{\dagger} \mathrm{IW}$, initial weight; ${ }^{\ddagger} \mathrm{FW}$, final weight; ${ }^{9} \mathrm{Fl}$, feed intake; ${ }^{\S} \mathrm{FCR}$, feed conversion ratio; ${ }^{\ddagger} \mathrm{PER}$, protein efficiency ratio; ${ }^{\#} \mathrm{PPV}$, protein productive value; ${ }^{\wedge} \mathrm{K}$, condition factor; ${ }^{\diamond} \mathrm{VSI}$, viscerosomatic index; ${ }^{\$} \mathrm{HSI}$, hepatosomatic index; ${ }^{\wedge} \mathrm{VFI}$, visceral fat index.

Means of triplicate groups; data in the same row with different superscripts differ at $p<0.05$; SEM: pooled standard error of the mean; Newman-Keuls test was applied for the comparison of the means. IW was considered as covariable for final weight. 
Table 3. $A D C$ of crude protein $(C P)$ and amino acids in the gilthead sea bream fed different experimental diets.

\begin{tabular}{|c|c|c|c|c|c|c|}
\hline & FM100 & FM50 & FM25+ & FM25 & FM0+ & FM0 \\
\hline$A D C_{C P}[\%]$ & 96.5 & 94.1 & 95.2 & 94.2 & 94.1 & 92.9 \\
\hline \multicolumn{7}{|l|}{$\mathrm{ADC}_{\mathrm{EAA}}[\%]$} \\
\hline Arginine & 96.2 & 93.5 & 94.8 & 90.3 & 93.1 & 89.2 \\
\hline Histidine & 95.7 & 94.9 & 96.9 & 94.1 & 94.5 & 93.4 \\
\hline Isoleucine & 96.4 & 94.2 & 97.1 & 93.5 & 95.7 & 92.2 \\
\hline Leucine & 96.4 & 95.1 & 96.8 & 94.8 & 96.2 & 93.0 \\
\hline Lysine & 97.8 & 96.7 & 97.0 & 94.8 & 97.5 & 93.9 \\
\hline Methionine & 97.2 & 96.3 & 97.1 & 96.1 & 97.3 & 96.3 \\
\hline Phenylalanine & 96.9 & 96.4 & 97.2 & 95.5 & 96.7 & 94.6 \\
\hline Threonine & 96.0 & 95.2 & 95.8 & 92.1 & 93.8 & 91.4 \\
\hline Valine & 96.1 & 94.8 & 96.3 & 93.6 & 94.9 & 91.2 \\
\hline \multicolumn{7}{|l|}{$\mathrm{ADC}_{\mathrm{NEAA}}[\%]$} \\
\hline Alanine & 96.0 & 96.3 & 97.0 & 94.8 & 95.2 & 90.6 \\
\hline Aspartate & 92.3 & 90.3 & 91.0 & 89.5 & 92.0 & 87.9 \\
\hline Cysteine & 91.6 & 90.9 & 91.6 & 90.1 & 90.5 & 89.0 \\
\hline Glutamine & 97.0 & 96.5 & 98.2 & 96.8 & 97.8 & 95.6 \\
\hline Glycine & 92.7 & 92.3 & 91.1 & 91.6 & 92.0 & 87.9 \\
\hline Proline & 96.4 & 94.8 & 96.8 & 95.1 & 97.0 & 94.9 \\
\hline Serine & 95.5 & 95.2 & 96.1 & 94.3 & 95.6 & 93.2 \\
\hline Tyrosine & 97.6 & 96.1 & 96.2 & 95.7 & 95.9 & 94.9 \\
\hline
\end{tabular}

${ }^{\dagger}$ EAA, essential amino acids; ${ }^{\ddagger} \mathrm{NEAA}$, non-essential amino acids

Table 4. Retention efficiencies of digested protein and digested essential amino acids in gilthead sea bream fed different experimental diets.

\begin{tabular}{llllllll}
\hline & FM100 & FM50 & FM25+ & FM25 & FM0+ & FM0 & SEM \\
\hline PDRE $^{\dagger}$ & 19.44 & 19.67 & 22.30 & 18.43 & 21.32 & 18.02 & 0.955 \\
AADRE & & & & & & \\
$\quad$ Arginine & 20.12 & 15.97 & 22.91 & 23.85 & 25.68 & 21.38 & 2.140 \\
$\quad$ Histidine & $20.09^{\mathrm{c}}$ & $18.21^{\mathrm{c}}$ & $29.81^{\mathrm{ab}}$ & $21.95^{\mathrm{bc}}$ & $31.25^{\mathrm{a}}$ & $21.61^{\mathrm{bc}}$ & 2.245 \\
Isoleucine & $24.07^{\mathrm{c}}$ & $26.62^{\mathrm{bc}}$ & $33.43^{\mathrm{ab}}$ & $27.26^{\mathrm{bc}}$ & $38.13^{\mathrm{a}}$ & $29.70^{\mathrm{bc}}$ & 1.999 \\
Leucine & $17.03^{\mathrm{b}}$ & $19.21^{\mathrm{b}}$ & $20.71^{\mathrm{b}}$ & $17.04^{\mathrm{b}}$ & $25.95^{\mathrm{a}}$ & $17.06^{\mathrm{b}}$ & 1.347 \\
Lysine & $19.45^{\mathrm{b}}$ & $25.44^{\mathrm{a}}$ & $28.17^{\mathrm{a}}$ & $28.54^{\mathrm{a}}$ & $29.17^{\mathrm{a}}$ & $28.39^{\mathrm{a}}$ & 1.884 \\
Methionine & 21.14 & 21.67 & 25.95 & 20.16 & 24.79 & 18.67 & 2.034 \\
Phenylalanine & $15.40^{\mathrm{ab}}$ & $15.86^{\mathrm{ab}}$ & $19.62^{\mathrm{a}}$ & $15.69^{\mathrm{ab}}$ & $19.84^{\mathrm{a}}$ & $12.34^{\mathrm{b}}$ & 1.320 \\
Threonine & 15.60 & 24.86 & 25.03 & 20.74 & 29.75 & 19.30 & 3.356 \\
Valine & $21.58^{\mathrm{c}}$ & $25.82^{\mathrm{bc}}$ & $32.00^{\mathrm{b}}$ & $26.87^{\mathrm{bc}}$ & $38.38^{\mathrm{a}}$ & $28.80^{\mathrm{b}}$ & 1.710 \\
\hline
\end{tabular}

${ }^{\dagger}$ PDRE, Protein Digestion Retention Efficiencies; ${ }^{\ddagger}$ ADRE, Amino acid Digestion Retention Efficiencies

$\operatorname{PDRE}[\%]=100 \cdot\left(\right.$ protein gain $[\mathrm{g}] /\left(\left(\mathrm{ADC} C_{\text {protein }} / 100\right) \cdot\right.$ protein ingested $\left.\left.[\mathrm{g}]\right)\right) ;$ AADRE $[\%]=100 \cdot($ amino acid gain $[\mathrm{g}] /$ $\left(\left(A D C_{\text {amino acid }} / 100\right) \cdot\right.$ amino acid ingested [g] $\left.)\right)$

Means of triplicate groups $(n=3)$; data in the same row with different superscripts differ at $p<0.05$; SEM: pooled standard error of the mean; Newman-Keuls test was applied to compare the means.

isoleucine, lysine and valine, in groups FM100 and FM50 for histidine and in group FM0 for phenylalanine.

\subsection{Ammonia excretion}

Accumulated ammonia excretion and ammonia excretion per $\mathrm{h}$ are shown in Figure 1. Accumulated ammonia excretion was significantly higher for diet FM0 from the first sampling point ( $2 \mathrm{~h}$ after feeding) to the end of the assay, which was mainly due to higher ammonia excretion during the first half of the experiment. There were significant differences in ammonia production in the first five two-h intervals after feeding, especially between groups FM0 and FM100, FM50 and FM25+. Statistical differences in 


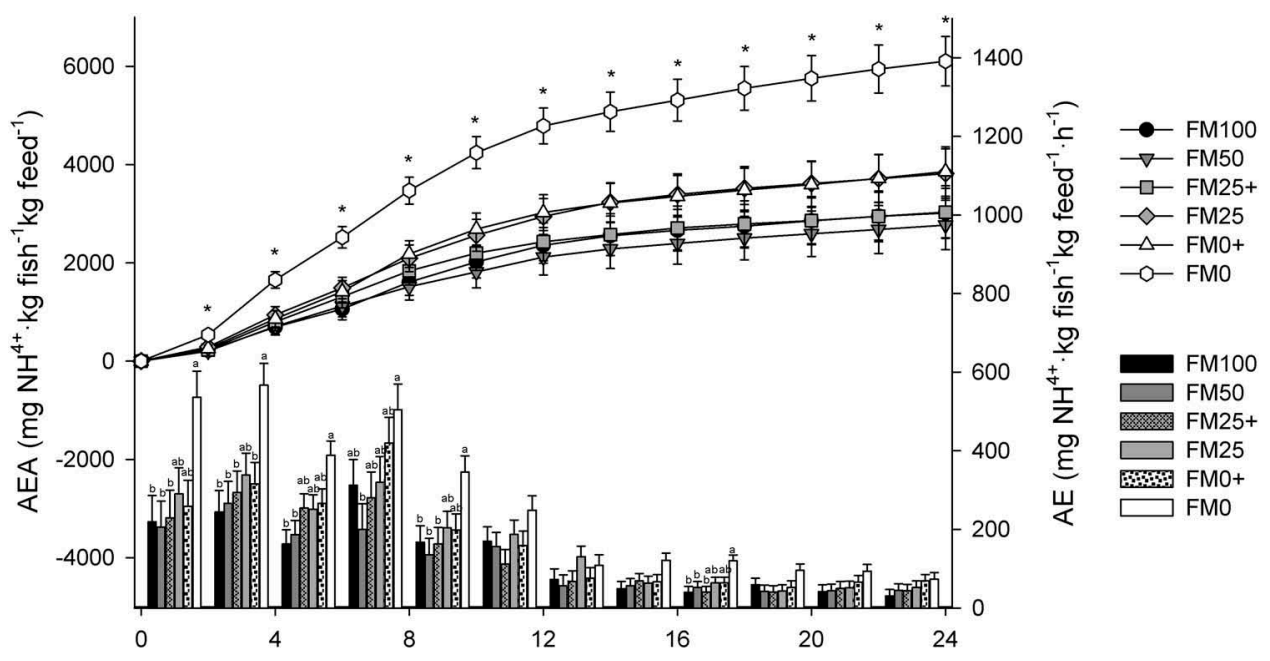

Figure 1. Ammonia excretion accumulation (AEA) and ammonia excretion (AE) per $\mathrm{h}$ in the different experimental groups.

Means of triplicate groups and standard error of the mean; asterisks indicate significant differences of the group FM0 in the AEA with the other groups, at $p<0.05$; different superscripts indicate differences between groups in the $\mathrm{AE}$, at $p<0.05$; Newman-Keuls test was applied to compare the means.

ammonia production were also determined between the $16^{\text {th }}$ and the $18^{\text {th }} \mathrm{h}$ after feeding. Maximum ammonia excretion values were determined at the $4^{\text {th }}$ (FM50, FM25+, FM25 and FM0) and $8^{\text {th }}$ h (FM100 and FM0+).

\subsection{Enzyme activity}

\subsubsection{Protease activity}

No significant differences were observed in pepsin activity in the stomachs of fish fed the different experimental diets (Figure 2(a)). A higher average value was obtained in group FM25+, followed by FM100, while the average activity registered in the other groups was very close. A similar pattern was observed in proteases activity in the gut tissue (Figure 2(b)). In this case, lower average activities of total alkaline protease and trypsin were observed in group FM0. Chymotrypsin activity was also determined in gut tissue, but the results are not shown since it was a very low or non-existent level.

No statistical differences were observed on proteases activity in GC samples (Figure 2(c)). The same pattern could be observed in the total alkaline protease, trypsin and chymotrypsin activity registered in the different experimental groups. The highest values were obtained, in this case, in group FM100. The ratio trypsin/chymotrypsin was similar for all experimental groups, although it was slightly lower for group FM0+.

\subsection{2. a-amylase activity}

There were no significant differences observed between experimental groups when $\alpha$ amylase activity was determined in gut tissue or gut content (Figure 2(d)). Highest average values were registered in group FM25+. 
a)
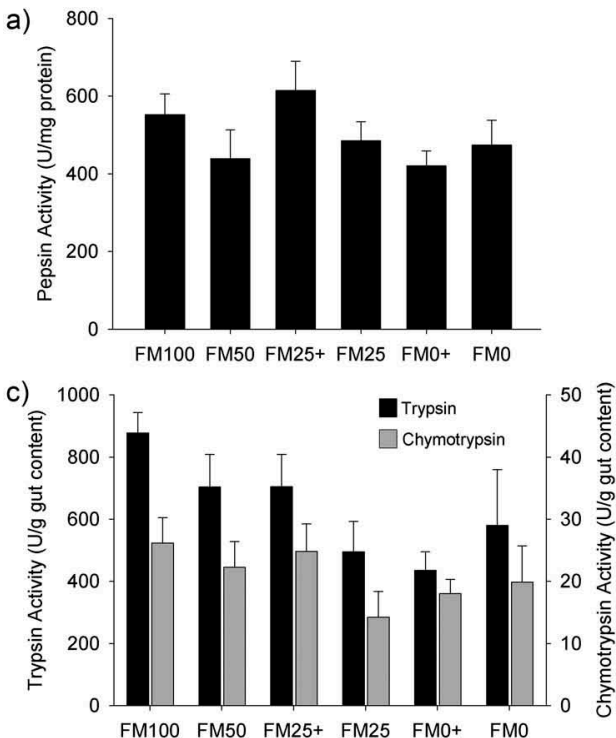

b)

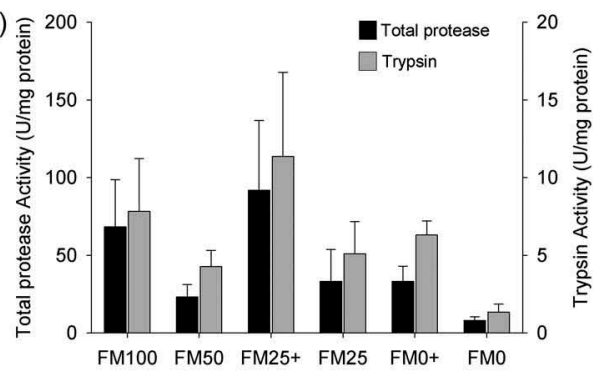

d)

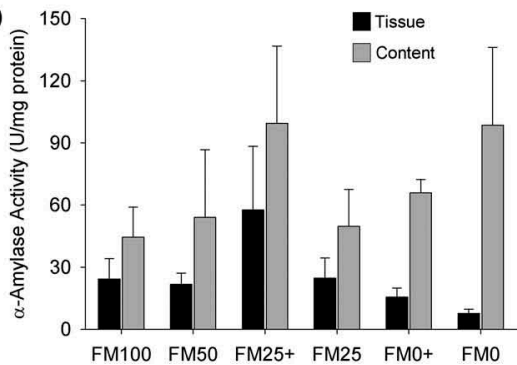

Figure 2. Enzymatic activity determined in the gastrointestinal tissue and contents of fish fed the different experimental diets.

a) Pepsin activity in stomach tissue; b) Total alkaline protease (black bars) and trypsin (grey bars) activity in gut tissue; c) Trypsin (black bars) and chymotrypsin (grey bars) activity in gut contents; d) $a$-amylase activity in gut tissue (black bars) and the gut contents (grey bars)Means of six fish per treatment $(n=6)$, in $\mathrm{U} / \mathrm{mg}$ protein or $\mathrm{U} / \mathrm{g}$ gut content, and standard error of the mean; different superscripts indicated differences, at $p<0.05$

\section{Discussion}

The inclusion of krill and squid meal in diets does not prove to have a positive attractant effect on fish on the present research work, in contrast to previous reports with squid and krill meal (Kader et al. 2012). In fact, higher values of FI were observed for the groups of fish fed with diets containing a partial or complete fishmeal substitution without squid and krill meal inclusion (FM50, FM25 and FM0). However, fish were fed to satiation and intake is regulated by fish according to the energy level of the feeds (Sánchez-Lozano et al. 2007). Thus, plant-based diets without marine-ingredient complementation could be deficient from an energetic point of view and it could dissemble a possible attractant effect. In this sense, although the different feeds assayed in this experiment were formulated as isoenergetic, digestive crude energy should be considered in further studies.

Despite fish in group FM25+ showed the lower FI value, this group reached the highest FW, even over group FM100. There were no statistical differences between groups FM100, FM50, FM25+, FM25 and FM0+, which suggests that high partial substitution of marine-origin ingredients does not have a negative impact on fish growth (Benedito-Palos et al. 2007; De Francesco et al. 2007; Dias et al. 2009), while a lower FW in group FM0 did confirm a negative effect on growth when diets with total replacement are used (Gómez-Requeni et al. 2004). Although there are reports of successful total substitution of fishmeal in terms of growth performance, the diets used contained a higher level of free amino acid supplementation (Kissil and Lupatsch 2004) or included small amounts of marine-origin ingredients (Monge- 
Ortiz et al. 2016). Thus, squid and krill meal inclusion has a positive effect on growth at the same level of fishmeal substitution, reducing the impact of fishmeal replacement.

As a consequence of higher FW and lower FI, group FM25+ showed a minor FCR and higher PER and PPV. As in other species (Torstensen et al. 2008), high plant protein inclusion does not seem to affect protein utilisation in gilthead sea bream and, in fact, it seems to be the most efficient food strategy for gilthead sea bream during the on-growing period. In contrast, total replacement seems to have a negative effect on protein utilisation, which will be discussed later.

It is important to point out that the group FM0 had a low survival rate. The number of casualties was particularly high in the last third of the trial, but no obvious signs of disease were observed in the dead fish. Although the causes of the increase in mortality in all groups remain unclear to this day, water was partially changed in the marine water recirculating system and consequently some bacteria could have been introduced into the system and have led to the death of weaker fish. Besides, high fishmeal replacement has been related with immune disorders (Sitjá-Bobadilla et al. 2005) and could explain the higher mortality in group FM0.

A significant impact of fishmeal replacement or inclusion of squid and krill meal was not observed in the biometric parameters or in the chemical composition of the fish. Only differences in the HSI were registered between fish fed the FM100 and FM0 diets, so the decrease of liver weight could be related to feed with high plant protein levels (Sánchez-Lozano et al. 2009; Martínez-Llorens et al. 2012), although this relation has not been observed in some previous studies (Linn et al. 2014; Monge-Ortiz et al. 2016).

Digestibility of dietary protein and EAA and their retention efficiency indices should be taken into account in the design of new diets in order to improve amino acids profile to better suit fish requirements. Differences in crude dietary protein digestibility are influenced by the content of anti-nutritional factors, the physicochemical properties of proteins or fibre level, among others (Martínez-Llorens et al. 2012), which affect amino acid availability (Francis et al. 2001). Moreover, since different amino acids are absorbed by the brush border membrane of the enterocytes through the same specific transporters with different affinities, differences on amino acid profile can compromise their availability and absorption (Berge et al. 2004), leading to variations in their digestibility and retention coefficients. Finally, the method for faeces collection should be considered, since the column or decantation method, used in the present work, normally gives higher ADC than other methods, such as the stripping method or the use of faeces collection devices (Vandenberg and De la Noüe 2001), due to nutrient leaching during the time between the release and the collection of the faeces (Spyridakis et al. 1989; Vandenberg and De la Noüe 2001). On the other hand, the stripping method seems to underestimate the digestibility coefficients, leading to stress events, possible disruptions of nutrients absorption and therefore to the obtention of samples in which the absorption process has not been completed (Clements and Raubenheimer 2006).

A slight decreasing trend in digestibility coefficients with higher levels of replacement has been observed in the present work, similarly to previous studies using the same faecal collection method (Dias et al. 2009), although higher differences were expected due to the higher fibre and NSP levels in diets with plant meals. Digestibility of EAA only differs slightly in the different experimental groups, except in the case of FM25 and FM0 and particularly for Arg, Ile, Lys, Thr and Val. Except for the FM0 group, the 
effects on fish growth, PER and PPV were minor, suggesting the other diets supply enough digestible EAA to meet nutritional requirements. On the other hand, a possible EAA imbalance caused by the different bioavailability of EAA which depends on the source (Santigosa et al. 2011), could be the reason of the poorer digestibility performance in the case of FM0. A positive effect of marine-complementary ingredients is observed in groups FM25+ and FM0+ in comparison to groups with equal dietary fishmeal. As aforementioned, these sources have proved to reduce deficits in aqua feeds with high levels of plant protein (Kolkovski et al. 2000), showing a more balanced amino acid profile and a high amount of free amino acids (Kader et al. 2012).

Since the EAA composition in fish bodies was the same for all dietary groups, AADREs were a reflection of the amino acid composition of the diets and they were greater in the dietary groups with a limited content of the different amino acids, particularly noticeable for group FM0+ and especially lower for group FM100, which showed higher level of dietary EAA (Sánchez-Lozano et al. 2009; Martínez-Llorens et al. 2012). In this sense, higher EAA retention has been reported in diets with higher levels of fishmeal substitution in similar previous studies (Gómez-Requeni et al. 2004; Sánchez-Lozano et al. 2009).

Ammonia excretion is a useful indirect tool to assess the metabolic use of protein in the diets (Velazco-Vargas et al. 2014) and, as a potentially toxic factor in aquaculture, its control is of great importance. Excess of dietary amino acids may be either not absorbed or metabolically derived, which leads to an increase of ammonia production (McGoogan and Gatlin 1999). Moreover, an increased excretion can be expected with a lower-level protein synthesis (Lied and Braaten 1984), also expressed as lower growth and protein retention (Bonaldo et al. 2011). Previous studies have reported an increase of ammonia production in response to high levels of vegetable meal inclusion in sea bream diets (Robaina et al. 1995; Bonaldo et al. 2011). In this sense, a higher ammonia excretion and lower growth and protein retention are observed in the diet with the highest inclusion of plant-based sources. Inasmuch as the protein dietary level is very similar in all experimental groups, the higher ammonia production in group FM0 in comparison to the other experimental groups can be explained by the lower digestibility of some EAA in this diet, which leads to an imbalance of ingested amino acids, a higher catabolism level of amino acids exceeding the required profile and, ultimately, a lower growth.

The ability of fish to digest and use nutrients depends on an appropriate performance of the different digestive enzymes (Vizcaíno et al. 2014). The source, quality and concentration of dietary nutrients can modulate the intestinal enzymatic profile (Santigosa et al. 2008), while the activity of these enzymes in the digestive tract can be used as an indicator of digestive capacity and nutritional status of the fish (Engrola et al. 2007). The use of plant-based alternative ingredients can lead to interferences with nutrient digestion and utilisation (Alarcón et al. 1999) due to anti-nutritional factors or enzyme inhibitors.

Previous studies have reported negative effects of plant protein sources on pepsin, alkaline protease, trypsin and chymotrypsin activity on sea bream (Santigosa et al. 2008; Silva et al. 2010), although impact at enzyme level did not always lead to differences in growth and feed utilisation (Monge-Ortiz et al. 2016). The results obtained in this research suggest that there is a certain effect of plant meal inclusion on the different protease activity in the gastrointestinal tissue and digestive contents, although there 
were no statistical differences observed between groups. As with growth and nutritive parameters, values obtained for group FM25+ in the intestinal tissue are the highest, showing the high digestive capacity of fish in this group. Nevertheless, differences in protease activity between different gut sections - not considered in the present work have been reported in different species, being a more decisive factor than the diet itself (Deguara et al. 2003; Sørensen et al. 2011; Hartviksen et al. 2014). Moreover, digestive capacity depends not only on enzyme level, but also on digestion time (i.e. the time during which the enzymes act on the nutrients) (Fountoulaki et al. 2005), which varies depending on protein source, since intestine length increases when high plant protein diets are used (Santigosa et al. 2008). Calculating the cumulative enzyme activity, from feeding time to $24 \mathrm{~h}$ after, can avoid variations due to sampling time and digestion patterns (Fountoulaki et al. 2005) and therefore should be taken into account in upcoming research, as well as sampling time after feeding (Venou et al. 2003; Yúfera et al. 2012), pH and temperature (Hidalgo et al. 1999; Deguara et al. 2003; Nikolopoulou et al. 2011).

Regarding amylase activity, previous studies show that the amylase activity can be positively influenced by the dietary carbohydrate level (Kuz'mina 1996), but negatively affected by the level of dietary starch and plant protein inclusion (Kokou et al. 2016). In the present study, diets with the highest level of plant meal showed a lower content of dietary starch (the level of carbohydrates is similar in all experimental diets) and the effects of both factors remain unclear, since no differences between groups were determined.

To conclude, in this article we have reported that a complete fishmeal substitution in gilthead sea bream diets during the on-growing period can be achieved without a high impact on biometric and biochemical parameters, protein and amino acid digestibility and enzyme activity. Nevertheless, the inclusion of marine-complementary ingredients such as squid and krill meal is necessary in lower percentages to avoid adverse effects on growth and nutritional efficiency parameters when a complete fishmeal replacement is performed.

\section{Acknowledgments}

The first author was supported by a contract-grant (Contrato Pre-doctoral para La Formación de Profesorado Universitario) from Subprogramas de Formación y Movilidad within the Programa Estatal de Promoción del Talento y su Empleabilidad of the Ministerio de Educación, Cultura y Deporte of Spain.

\section{Disclosure statement}

No potential conflict of interest was reported by the authors.

\section{Funding}

This work was supported by the Vicerrectorat d'Investigació, Innovació i Transferència of the Universitat Politècnica de València, within the project Aquaculture feed without fishmeal (SP20120603). URLs of funder: http://www.upv.es/entidades/VIIT/info/indexnormalc.htm. The funders had no role in study design, data collection and analysis, decision to publish, or preparation of the manuscript. 


\section{ORCID}

Guillem Estruch (1) http://orcid.org/0000-0001-8722-0556

Sergio Godoy-Olmos (10) http://orcid.org/0000-0003-1589-7562

Silvia Martínez-Llorens (i) http://orcid.org/0000-0002-9824-3267

\section{References}

Alarcón FJ, Moyano FJ, Díaz M. 1999. Effect of inhibitors present in protein sources on digestive proteases of juvenile sea bream (Sparus aurata). Aquat Living Resour. 12:233-238.

Anson ML. 1938. The estimation of pepsin, trypsin, papain, and cathepsin with hemoglobin. J Gen Physiol. 22:79-89.

[AOAC] Association of Official Analytical Chemists. 1995. Official methods of analysis. Washington, DC: AOAC.

Benedito-Palos L, Saera-Vila A, Calduch-Giner JA, Kaushik S, Pérez-Sánchez J. 2007. Combined replacement of fish meal and oil in practical diets for fast growing juveniles of gilthead sea bream (Sparus aurata L.): networking of systemic and local components of GH/IGF axis. Aquaculture. 267:199-212.

Berge GE, Goodman M, Espe M, Lied E. 2004. Intestinal absorption of amino acids in fish: kinetics and interaction of the in vitro uptake of L-methionine in Atlantic salmon (Salmo salar L.). Aquaculture. 229:265-273.

Bonaldo A, Parma L, Mandrioli L, Sirri R, Fontanillas R, Badiani A, Gatta PP. 2011. Increasing dietary plant proteins affects growth performance and ammonia excretion but not digestibility and gut histology in turbot (Psetta maxima) juveniles. Aquaculture. 318:101-108.

Bosch L, Alegria A, Farré R. 2006. Application of the 6-aminoquinolyl-N-hydroxysccinimidyl carbamate (AQC) reagent to the RP-HPLC determination of amino acids in infant foods. J Chromatogr B. 831:176-183.

Bowyer JN, Qin JG, Smullen RP, Adams LR, Thomson MJS, Stone DAJ. 2013. The use of a soy product in juvenile yellowtail king fish (Seriola lalandi) feeds at different water temperatures: 2. Soy protein concentrate. Aquaculture. 410-411:1-10.

Bradford MM. 1976. A rapid and sensitive method for the quantitation of microgram quantities of protein utilizing the principle of protein dye-binding. Anal Biochem. 72:248-254.

Cahu C, Zambonino Infante J. 2001. Substitution of live food by formulated diets in marine fish larvae. Aquaculture. 200:161-180.

Cho CY, Slinger SJ, Bayley HS. 1982. Bioenergetics of salmonid fishes: energy intake, expenditure and productivity. Comp Biochem Physiol Part B. 73:25-41.

Clements KD, Raubenheimer D. 2006. Chapter 2: feeding and nutrition. In: Evans DH, Claiborne JB, editors. The physiology of fishes. 3rd ed. Boca Raton (FL): Taylor and Francis.

De Francesco M, Parisi G, Pérez-Sánchez J, Gómez-Requeni P, Médale F, Kaushik SJ, Mecatti M, Poli BM. 2007. Effect of high-level fish meal replacement by plant proteins in gilthead sea bream (Sparus aurata) on growth and body/fillet quality traits. Aquac Nutr. 13:361-372.

Deguara S, Jauncey K, Agius C. 2003. Enzyme activities and pH variations in the digestive tract of gilthead sea bream. J Fish Biol. 62:1033-1043.

Dias J, Conceição LEC, Ramalho A, Borges P, Valente LMP, Teresa M. 2009. Practical diet with low fish-derived protein is able to sustain growth performance in gilthead seabream (Sparus aurata) during the grow-out phase. Aquaculture. 293:255-262.

Díaz-López M, Moyano-López FJ, Alarcon-López FJ, García-Carreño FL, Navarrete Del Toro MA. 1998. Characterization of fish acid proteases by substrate - gel electrophoresis. Comp Biochem Physiol Part B. 121:369-377.

Engrola S, Conceiçao LEC, Dias L, Pereira R, Ribeiro L, Dinis MT. 2007. Improving weaning strategies for Senegalese sole : effects of body weight and digestive capacity. Aquac Res. 38:696-707. 
Erlanger BF, Kokowsky N, Cohen W. 1961. The preparation and properties of two new chromogenic substrates of trypsin. Arch Biochem Biophys. 95:271-278.

Fountoulaki E, Alexis MN, Nengas I, Venou B. 2005. Effect of diet composition on nutrient digestibility and digestive enzyme levels of gilthead sea bream (Sparus aurata L.). Aquac Res. 36:1243-1251.

Francis G, Makkar HPS, Becker K. 2001. Antinutritional factors present in plant-derived alternate fish feed ingredients and their effects in fish. Aquaculture. 199:197-227.

García García B, Cerezo Valverde J, Gómez E, Hernández MD, Aguado-Giménez F. 2011. Ammonia excretion of octopus (Octopus vulgaris) in relation to body weight and protein intake. Aquaculture. 319:162-167.

Gomes EF, Rema P, Gouveia A, Oliva-Teles A. 1995. Replacement of fish meal by plant proteins in diets for rainbow trout (Oncorhynchus mykiss): effect of the quality of the fishmeal based control diets on digestibility and nutrient balances. Water Sci Technol. 31:205-211.

Gómez-Requeni P, Mingarro M, Calduch-Giner JA, Médale F, Martin SAM, Houlihan DF, Kaushik S, Pérez-Sánchez J. 2004. Protein growth performance, amino acid utilisation and somatotropic axis responsiveness to fish meal replacement by plant protein sources in gilthead sea bream (Sparus aurata). Aquaculture. 232:493-510.

Hartviksen M, Bakke AM, Vecino JG, Ringø E, Krogdahl Å. 2014. Evaluation of the effect of commercially available plant and animal protein sources in diets for Atlantic salmon (Salmo salar L.): digestive and metabolic investigations. Fish Physiol Biochem. 40:1621-1637.

Hidalgo MC, Urea E, Sanz A. 1999. Comparative study of digestive enzymes in fish with different nutritional habits. Proteolytic and amylase activities. Aquaculture. 170:267-283.

Kader MA, Bulbul M, Koshio S, Ishikawa M, Yokoyama S, Nguyen BT, Komilus CF. 2012. Effect of complete replacement of fishmeal by dehulled soybean meal with crude attractants supplementation in diets for red sea bream, Pagrus major. Aquaculture. 350353:109-116.

Kader MA, Koshio S, Ishikawa M, Yokoyama S, Bulbul M. 2010. Supplemental effects of some crude ingredients in improving nutritive values of low fishmeal diets for red sea bream, Pagrus major. Aquaculture. 308:136-144.

Kissil G, Lupatsch I. 2004. Successful replacement of fishmeal by plant proteins in diets for the gilthead seabream, Sparus aurata L. Isr J Aquac - Bamidgeh. 56:188-199.

Kokou F, Rigos G, Kentouri M, Alexis M. 2016. Effects of DL-methionine-supplemented dietary soy protein concentrate on growth performance and intestinal enzyme activity of gilthead sea bream. Aquac Int. 24:257-271.

Kolkovski S, Czesny S, Dabrowski K. 2000. Use of krill hydrolysate as a feed attractant for fish larvae and juveniles. J World Aquac Soc. 31:81-88.

Kunitz M. 1947. Isolation of a crystalline protein compound of trypsin and of soybean trypsin inhibitor. J Gen Physiol. 30:311-320.

Kuz'mina VV. 1996. Influence of age on digestive enzyme activity in some freshwater teleosts. Aquaculture. 148:25-37.

Lied E, Braaten B. 1984. The effect of feeding and starving, and different ratios of protein energy to total energy in the feed on the excretion of ammonia in Atlantic cod (Gadus morhua). Comp Biochem Physiol. 78A:49-52.

Linn SM, Ishikawa M, Koshio S, Yokoyama S, Murata T, Hamasaki Y, Nankervis L. 2014. Effects of replacing fish meal with plant protein on growth performance, feed utilization and oxidative condition of red sea bream pagrus major. Aquac Sci. 62:341-352.

Mai K, Li H, Ai Q, Duan Q, Xu W, Zhang C, Zhang L, Tan B, Liufu Z. 2006. Effects of dietary squid viscera meal on growth and cadmium accumulation in tissues of Japanese seabass, Lateolabrax japonicus (Cuvier 1828). Aquac Res. 37:1063-1069.

Martínez-Llorens S, Baeza-Ariño R, Nogales-Mérida S, Jover-Cerdá M, Tomás-Vidal A. 2012. Carob seed germ meal as a partial substitute in gilthead sea bream (Sparus aurata) diets: amino acid retention, digestibility, gut and liver histology. Aquaculture. 338-341:124-133. 
Martínez-Llorens S, Moñino AV, Tomás Vidal A, Salvador VJM, Pla Torres M, Jover Cerdá M. 2007. Soybean meal as a protein source in gilthead sea bream (Sparus aurata L.) diets: effects on growth and nutrient utilization. Aquac Res. 38:82-90.

McGoogan BB, Gatlin DM III. 1999. Dietary manipulations affecting growth and nitrogenous waste production of red drum, Sciaenops ocellatus I. Effects of dietary protein and energy levels. Aquaculture. 178:333-348.

Monge-Ortiz R, Martínez-Llorens S, Márquez L, Moyano FJ, Jover-Cerdá M, Tomás-Vidal A. 2016. Potential use of high levels of vegetal proteins in diets for market-sized gilthead sea bream (Sparus aurata). Arch Anim Nutr. 70:155-172.

Nikolopoulou D, Moutou KA, Fountoulaki E, Venou B, Adamidou S, Alexis MN. 2011. Comparative biochemistry and physiology, part A patterns of gastric evacuation, digesta characteristics and $\mathrm{pH}$ changes along the gastrointestinal tract of gilthead sea bream (Sparus aurata L.) and European sea bass (Dicentrarchus labrax L.). Comp Biochem Physiol Part. 158:406-414.

Pereira TG, Oliva-Teles A. 2002. Preliminary evaluation of pea seed meal in diets for gilthead sea bream (Sparus aurata) juveniles. Aquac Res. 33:1183-1189.

Pereira TG, Oliva-Teles A. 2003. Evaluation of corn gluten meal as a protein source in diets for gilthead sea bream (Sparus aurata L.) juveniles. Aquac Res. 34:1111-1117.

Pereira TG, Oliva-Teles A. 2004. Evaluation of micronized lupin seed meal as an alternative protein source in diets for gilthead sea bream Sparus aurata L. juveniles. Aquac Res. 35:828-835.

Peres H, Oliva-Teles A. 2009. The optimum dietary essential amino acid profile for gilthead seabream (Sparus aurata) juveniles. Aquaculture. 296:81-86.

Real Decreto 53/2013 sobre protección de animales utilizados en experimentación y otros fines científicos. 2013. Boletín Oficial del Estado. 34: 11370-11371.

Robaina L, Izquierdo MS, Moyano FJ, Socorro J, Vergara JM, Montero D, Fernández-Palacios H. 1995. Soybean and lupin seed meals as protein sources in diets for gilthead seabream (Sparus aurata): nutritional and histological implications. Aquaculture. 130:219-233.

Sánchez-Lozano NB, Martínez-Llorens S, Tomás-Vidal A, Jover Cerdá M. 2009. Effect of highlevel fish meal replacement by pea and rice concentrate protein on growth, nutrient utilization and fillet quality in gilthead seabream (Sparus aurata, L.). Aquaculture. 298:83-89.

Sánchez-Lozano NB, Tomás Vidal A, Martínez-Llorens S, Nogales Mérida S, Espert Blanco J, Moñino López A, Pla Torres M, Jover Cerdá M. 2007. Growth and economic profit of gilthead sea bream (Sparus aurata, L.) fed sunflower meal. Aquaculture. 272:528-534.

Santigosa E, García-Meilán I, Valentin JM, Pérez-Sánchez J, Médale F, Kaushik S, Gallardo MA. 2011. Modi fi cations of intestinal nutrient absorption in response to dietary fi sh meal replacement by plant protein sources in sea bream (Sparus aurata) and rainbow trout (Onchorynchus mykiss). Aquaculture. 317:146-154.

Santigosa E, Sánchez J, Médale F, Kaushik S, Pérez-Sánchez J, Gallardo MA. 2008. Modifications of digestive enzymes in trout (Oncorhynchus mykiss) and sea bream (Sparus aurata) in response to dietary fish meal replacement by plant protein sources. Aquaculture. 282:68-74.

Silva FCP, Nicoli JR, Zambonino-Infante JL, Le Gall MM, Kaushik S, Gatesoupe FJ. 2010. Influence of partial substitution of dietary fi sh meal on the activity of digestive enzymes in the intestinal brush border membrane of gilthead sea bream, Sparus aurata and gold fish, Carassius auratus. Aquaculture. 306:233-237.

Sitjá-Bobadilla A, Peña-Llopis S, Gómez-Requeni P, Médale F, Kaushik S, Pérez-Sánchez J. 2005. Effect of fish meal replacement by plant protein sources on non-specific defence mechanisms and oxidative stress in gilthead sea bream (Sparus aurata). Aquaculture. 249:387-400.

Sørensen M, Penn M, El-Mowa A, Storebakken T, Chunfang C, Øverland M, Krogdahl Å. 2011. Effect of stachyose, raffinose and soya-saponins supplementation on nutrient digestibility, digestive enzymes, gut morphology and growth performance in Atlantic salmon (Salmo salar, L.). Aquaculture. 314:145-152. 
Spyridakis P, Metailler R, Gabaudan J, Riaza A. 1989. Studies on nutrient digestibility in european sea bass (Dicentrarchus labrax). 1. Methodological aspects concerning faeces collection. Aquaculture. 77:61-70.

Statgraphics @ Centurion XVI.Rockville (MO): Statistical Graphics Corp.; www.statgraphics.com. Torstensen BE, Espe M, Sanden M, Stubhaug I, Waagbø R, Hemre GI, Fontanillas R, Nordgarden U, Hevrøy EM, Olsvik P, et al. 2008. Novel production of Atlantic salmon (Salmo salar) protein based on combined replacement of fish meal and fish oil with plant meal and vegetable oil blends. Aquaculture. 285:193-200.

Vandenberg GW, De la Noüe J. 2001. Apparent digestibility comparison in rainbow trout (Oncorhynchus mykiss) assessed using three methods of faeces collection and three digestibility markers. Aquac Nutr. 7:237-245.

Velazco-Vargas J, Tomás-Vidal A, Hamdan M, Moyano-López FJ, Jover Cerdá M, MartínezLlorens S. 2014. Influence of digestible protein levels on growth and feed utilization of juvenile meagre argyrosomus regius. Aquac Nutr. 20:520-531.

Venou B, Alexis MN, Fountoulaki E, Nengas I, Apostolopoulou M, Castritsi-Cathariou I. 2003. Effect of extrusion of wheat and corn on gilthead sea bream (Sparus aurata) growth, nutrient utilization efficiency, rates of gastric evacuation and digestive enzyme activities. Aquaculture. 225:207-223.

Vizcaíno AJ, López G, Sáez MI, Jiménez JA, Barros A, Hidalgo L, Camacho-Rodríguez J, Martínez TF, Cerón-García MC, Alarcón FJ. 2014. Effects of the microalga Scenedesmus almeriensis as fishmeal alternative in diets for gilthead sea bream, Sparus aurata, juveniles. Aquaculture. 431:34-43.

Walter HE. 1984. Proteinases: methods with hemoglobin, casein and azocoll as substrates. Methods Enzymatic Analysis. 5:270-277.

Yúfera M, Moyano FJ, Astola A, Pousao-Ferreira P, Martínez-Rodríguez G. 2012. Acidic digestion in a teleost: postprandial and circadian pattern of gastric $\mathrm{pH}$, pepsin activity, and pepsinogen and proton pump mRNAs expression. PLoS One. 7:1-9. 